\title{
The detection of post-monsoon tropospheric ozone variability over south Asia using IASI data
}

\author{
B. Barret ${ }^{1,2}$, E. Le Flochmoen ${ }^{1,2}$, B. Sauvage ${ }^{1,2}$, E. Pavelin ${ }^{3}$, M. Matricardi ${ }^{4}$, and J. P. Cammas ${ }^{1,2}$ \\ ${ }^{1}$ Laboratoire d'Aérologie/OMP, Université de Toulouse, Toulouse, France \\ ${ }^{2}$ CNRS UMR 5560, 14 avenue E. Belin, 31400 Toulouse, France \\ ${ }^{3}$ Met Office, FitzRoy Road, Exeter, Devon, EX1 3PB, UK \\ ${ }^{4}$ ECMWF, Shinfield Park, Reading, RG2 9AX, UK
}

Received: 9 November 2010 - Published in Atmos. Chem. Phys. Discuss.: 25 March 2011

Revised: 13 July 2011 - Accepted: 6 September 2011 - Published: 16 September 2011

\begin{abstract}
The ozone $\left(\mathrm{O}_{3}\right)$ variability over south Asia during the 2008 post-monsoon season has been assessed using measurements from the MetOP-A/IASI instrument and $\mathrm{O}_{3}$ profiles retrieved with the SOftware for a Fast Retrieval of IASI Data (SOFRID). The information content study and error analyses carried out in this paper show that IASI Level 1 data can be used to retrieve tropospheric $\mathrm{O}_{3}$ columns (TOC, surface-225 hPa) and UTLS columns (225-70 hPa) with errors smaller than $20 \%$. Validation with global radiosonde $\mathrm{O}_{3}$ profiles obtained during a period of 6 months show the excellent agreement between IASI and radiosonde for the UTLS with correlation coefficient $R>0.91$ and good agreement in the troposphere with correlation coefficient $R>0.74$. For both the UTLS and the troposphere Relative Standard Deviations (RSD) are lower than $23 \%$. Comparison with in-situ measurements from the MOZAIC program around Hyderabad demonstrates that IASI is able to capture the TOC inter and intra-seasonal variability in central India. Nevertheless, the agreement is mitigated by the fact that the smoothing of the true $\mathrm{O}_{3}$ profiles by the retrieval results in a reduction of the TOC variability detected by IASI relative to the variability observed by in situ instruments. The post-monsoon temporal variability of the vertical profile of $\mathrm{O}_{3}$ around Hyderabad has been investigated with MOZAIC observations. These observations from airborne instruments show that tropospheric $\mathrm{O}_{3}$ is steadily elevated during most of the studied period with the exception of two sharp drops following the crossing of tropical storms over India. Lagrangian simulations with the FLEXPART model indicate that elevated $\mathrm{O}_{3}$ concentrations in the middle troposphere near Hyderabad are associated with the transport of UTLS air-masses that
\end{abstract}

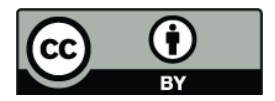

Correspondence to: B. Brice

(barp@aero.obs-mip.fr) have followed the Subtropical Westerly Jet (SWJ) and subsided over northern India together with boundary layer polluted air-masses transported from the Indo-gangetic plain by the north-easterly trades. Low $\mathrm{O}_{3}$ concentrations result from the uplift and westward transport of pristine air-masses from the marine boundary layer of the Bay of Bengal by tropical storms. In order to extend the analysis of tropospheric $\mathrm{O}_{3}$ variability to the whole of south Asia, we have used IASISOFRID $\mathrm{O}_{3}$ data. We show that IASI $\mathrm{O}_{3}$ data around $\mathrm{Hy}-$ derabad were able to capture the fast variability revealed by MOZAIC. Furthermore, their spatio-temporal coverage demonstrates that the behaviour of tropospheric $\mathrm{O}_{3}$ observed near Hyderabad extended over most of central and south India and part of the Bay of Bengal. This result highlights the ability of the IASI sensor to capture fast changes in chemical composition related to dramatic tropical weather conditions.

\section{Introduction}

According to Dentener et al. (2006), south Asia may become the most $\mathrm{O}_{3}$ polluted region with an average $52.2 \mathrm{ppbv}$ surface concentration by 2030. The outflow of pollution from south Asia towards the Indian Ocean during the winter season has been investigated through the Indian Ocean Experiment (INDOEX) multiplatform field campaign (Lelieveld et al., 2001). Cloud-free conditions promote strong photochemical activity within the polluted air masses exported from India, leading to elevated $\mathrm{O}_{3}$ concentrations off the Indian coasts (Lawrence and Lelieveld, 2010). This fast photochemical $\mathrm{O}_{3}$ production within the continental outflow is supported by shipboard measurements of surface $\mathrm{O}_{3}$ mixing ratios exceeding $70 \mathrm{ppbv}$ over the Arabian Sea in contrast with lower concentrations (25-35 ppbv) measured in

Published by Copernicus Publications on behalf of the European Geosciences Union. 
coastal cities (Lal and Lawrence, 2001). According to Lal et al. (2006) high levels of surface $\mathrm{O}_{3}$ over the Bay of Bengal can also be explained by transport from the continent. Based on shipboard radiosoundings and on Total Tropospheric $\mathrm{O}_{3}$ (TTO) derived from the TOMS satellite sensor, Chatfield et al. (2007) proposed some mechanisms to explain the variability of tropospheric $\mathrm{O}_{3}$ during the winter season over the Indian Ocean. They have shown that $\mathrm{O}_{3}$ maxima in the middle troposphere over the northern Indian Ocean originate alternatively from venting of lower tropospheric pollution and from stratospheric intrusion.

Most of the above-mentioned studies are based on campaign-based measurements because south Asia lacks of regular in-situ observations of tropospheric $\mathrm{O}_{3}$. Concerning space-based observations, TTO from TOMS used by Chatfield et al. (2007) are mostly sensitive to the upper troposphere. Furthermore TTO data as derived from Chatfield et al. (2007) assign the zonal wavenumber 1 component of the TOMS signal to the troposphere, an assumption valid only between $10^{\circ} \mathrm{S}$ and $10^{\circ} \mathrm{N}$. The nadir thermal infrared Aura/TES sensor (Beer et al., 2001) is able to discriminate middle-tropospheric from upper tropospheric $\mathrm{O}_{3}$ but is characterized by a limited spatial coverage (nadir only). $\mathrm{O}_{3}$ data from TES have in particular been used to characterize the monthly mid-tropospheric distributions of $\mathrm{O}_{3}$ over Asia during the summer monsoon season (Worden et al., 2009). The chemical and dynamical processes that control tropical $\mathrm{O}_{3}$ have interannual to daily variabilities and further understanding of these processes requires data with a daily sampling as mentioned in the concluding remarks of Chatfield et al. (2007) . Thanks to its large across-track scanning angle, the thermal infrared Metop/IASI sensor permits a global daily coverage. Eremenko et al. (2009) have shown that the Metop/IASI sensor was able to capture increased concentrations of tropospheric $\mathrm{O}_{3}$ over eastern Europe during a heatwave. Our aim is to demonstrate the ability of IASI to provide daily global tropospheric $\mathrm{O}_{3}$ soundings enabling the monitoring and forecast of chemical, as well as conventional, weather. Our case study is focused over south Asia during the post-monsoon period. This choice has been made mainly because during this period south Asia is characterized by heavy pollution and by fast and large-scale variability of the tropospheric circulation potentially impacting the tropospheric $\mathrm{O}_{3}$ distribution. Secondly IASI tropospheric $\mathrm{O}_{3}$ data have not yet been used over tropical regions at the continental scale. Our aim is also to further understand the factors controlling this observed variability. In Sect. 2, we introduce our IASI $\mathrm{O}_{3}$ retrievals, their characterization in terms of vertical sensitivity and error budget and their validation with in situ radiosounding measurements and observations from the MOZAIC program. Section 3 is dedicated to the characterization of the post-monsoon tropospheric $\mathrm{O}_{3}$ variability over south Asia. We use high precision $\mathrm{O}_{3}$ in situ MOZAIC observations to study the situation near Hyderabad in central India. A detailed transport analysis relying on Lagrangian disper- sion modelling is performed to determine the main factors controlling the observed $\mathrm{O}_{3}$ variability. IASI data are finally put forward to characterize the post-monsoon $\mathrm{O}_{3}$ variability over the whole south Asian region.

\section{The IASI-SOFRID $\mathrm{O}_{3}$ retrievals}

\subsection{The IASI instrument}

The IASI instrument has been developed to fly on board the MetOp platforms (the first platform, MetOp-A, successfully launched in 2006). IASI is a nadir viewing Fourier transform spectrometer observing the Earth-atmosphere Thermal Infrared Radiation (TIR) in the $645-2760 \mathrm{~cm}^{-1}$ wavenumber region (see e.g. Clerbaux et al., 2009). It is characterized by a moderate spectral resolution of $0.5 \mathrm{~cm}^{-1}$ after apodization, and a low noise level. IASI scans the Earth surface across the satellite flight track with a maximum $48.3^{\circ}$ angle from nadir corresponding to a $1100 \mathrm{~km}$ distance. From the MetOp sunsynchronous orbit IASI is recording about 1.4 million pixels per day during daytime (09:30 local time) and nightime (21:30). At nadir, each view is $50 \times 50 \mathrm{~km}$ wide and consists of an array of $2 \times 2$ individual pixels each characterized by a $12 \mathrm{~km}$ footprint. Aimed primarily at retrieving atmospheric humidity and temperature in order to improve weather forecasting, IASI also allows us to determine concentrations of atmospheric trace gases such as $\mathrm{O}_{3}$ (Eremenko et al., 2009; Boynard et al., 2009) and CO (George et al., 2009).

\subsection{The SOFRID retrieval algorithm}

In order to retrieve $\mathrm{O}_{3}$ vertical profiles from IASI radiances, we have developed the Software for a Fast Retrieval of IASI Data (SOFRID) based on the RTTOV (Radiative Transfer for TOVS) fast radiative transfer model. The RTTOV model (Saunders, 1999; Matricardi et al., 2004) is developed jointly by the UK Met Office (UKMO), the European Center for Medium Range Weather Forecasts (ECMWF) and Meteo France. RTTOV uses a parameterization of atmospheric optical depths that makes the model accurate and fast enough to be used for the operational assimilation of satellite radiance data in Numerical Weather Prediction (NWP). In RTTOV, the optical depths are expressed as a linear combination of profile dependent predictors that are functions of temperature, absorber amount, pressure and viewing angle. The RTTOV optical depths are computed using regression coefficients derived from accurate line-by-line (LBL) computations performed using the LBL Radiative Transfer Model (LBLRTM Clough et al., 2005). For IASI, RTTOV can reproduce the underlying LBL radiances to an accuracy that is typically below $0.1 \mathrm{~K}$. The overall accuracy of RTTOV is discussed in detail by Matricardi et al. (2009). In this paper we use RTTOV regression coefficients based on LBL computations performed using the HITRAN2004 spectroscopic 
(a)

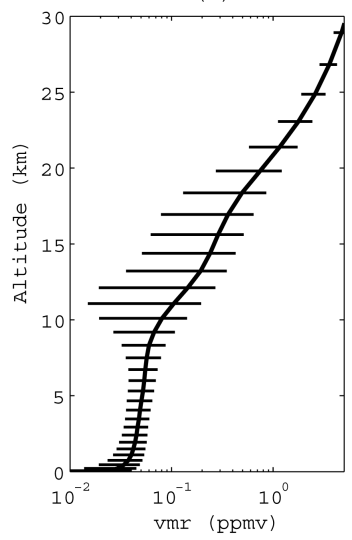

(b)

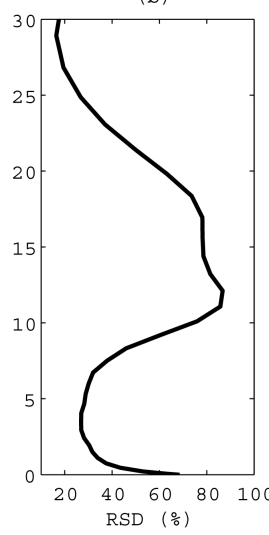

(c)

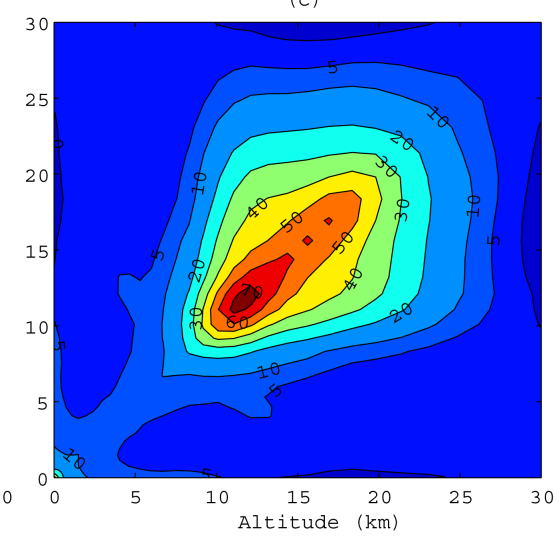

Fig. 1. a priori $\mathrm{O}_{3}$ data computed from the WOUDC, SHADOZ and MOZAIC database: (a) mean profile and associated variabilities, (b) Relative Standard Deviations (RSD), (c) relative covariance matrix in \%.

database (Rothman et al., 2005). The land surface emmisivity is computed with the RTTOV UW-IRemis module (Borbas et al., 2010). This module is based on a principal component analysis regression relationship between the MODIS MOD11-based UW Global Infrared Land Surface Emissivity Database (Seemann et al., 2008) and a set of selected laboratory emissivity measurements (ICESS/UCSB) that are representative of surfaces and soils present in global ecosystems.

The retrieval of $\mathrm{O}_{3}$ concentration profiles from TIR spaceborne radiances is an underconstrained problem that requires additional information to be regularised. Our retrievals are performed with the UKMO 1D-Var algorithm (Pavelin et al., 2008) based on the Optimal Estimation Method (OEM) (Rodgers, 2000). In the OEM, the additional regularisation constraint comes from an ensemble representing the best a priori knowledge of the atmospheric state to be retrieved (in our case, the $\mathrm{O}_{3}$ vertical profile). The retrieved state is the combination of the measured radiances and the a priori state inversely weighted by their covariance matrices. The retrieval being also a non-linear problem requires linearization of the radiative transfer equation and iteration until convergence is obtained.

Our $\mathrm{O}_{3}$ a priori state, $\boldsymbol{x}_{a}$ and covariance matrix, $\mathbf{S}_{\mathrm{a}}$ are based on an ensemble of in-situ $\mathrm{O}_{3}$ profiles measured in 2008 by radiosounding ( $~ 800$ profiles) from the WOUDC (World Ozone and Ultraviolet Radiation Data Centre) and SHADOZ (Southern Hemisphere ADditional OZonesondes, Thompson et al., 2003) networks and taken at landing and take-off by the MOZAIC (Measurements of OZone, water vapour, carbon monoxide and nitrogen oxides by in-service AIrbus airCraft, Thouret et al., 1998) instrumented aircraft ( $\sim 1600$ profiles). Because of the WOUDC and MOZAIC geographical sampling, the a priori is biased towards midlatitudes with relatively high $\mathrm{O}_{3}$ concentrations in the lower troposphere and a steep increase above $300 \mathrm{hPa}$ characteris- tic of a mid-latitude tropopause height (Fig. 1a). The profiles are completed above $220 \mathrm{hPa}$ by coincident $\mathrm{O}_{3}$ profiles from Aura/MLS assimilated data. The MLS UTLS $\mathrm{O}_{3}$ data are described and validated in Livesey et al. (2007). El Amraoui et al. (2010) provide a brief description of the MLS assimilated data and show that they agree very well with MOZAIC UTLS observations in the mid-latitudes in summer. A complete description and a thorough validation of the assimilated $\mathrm{O}_{3}$ profiles are given in Massart et al. (2011). In particular, Massart et al. (2011) show that above $220 \mathrm{hPa}$ the assimilated profiles have biases lower than $20 \%$ and RSD of the differences lower than $40 \%$ (20\% in the tropics) relative to ozonesondes in the different latitude regions. The biases and the RSD of the differences decrease to less than $10 \%$ in the stratosphere. The corresponding a priori $\mathrm{O}_{3}$ variability is shown in Fig. 1b. The highest $\mathrm{O}_{3}$ variability $(\sim 90 \%)$ in the Upper Troposphere-Lower Stratosphere (UTLS) is due to the large tropopause variations within the ensemble of $\mathrm{O}_{3}$ profiles from $300 \mathrm{hPa}(9 \mathrm{~km})$ at high latitudes in winter to $100 \mathrm{hPa}(16 \mathrm{~km})$ in the tropics. On both side of the tropopause, the $\mathrm{O}_{3} \mathrm{vmr}$ variations are very steep from less than $100 \mathrm{ppbv}$ in the upper troposphere to several ppmv in the lower stratosphere. The relative covariance matrix is displayed in Fig. 1c. The ith $\mathrm{x}$ jth element of this matrix is computed as the ratio of the correponding covariance matrix element by the product of the ith and jth elements of the mean $\mathrm{O}_{3}$ profile. It shows that $\mathrm{O}_{3}$ concentrations are highly correlated throughout the lower to middle stratosphere where $\mathrm{O}_{3}$ is controlled by transport processes whilst lower tropospheric $\mathrm{O}_{3}$ is little correlated to upper tropospheric $\mathrm{O}_{3}$.

We use EUMETSAT operational IASI level 2 products for the temperature and water vapor atmospheric profiles required for the radiative transfer computations. These atmospheric parameters are held constant during the retrieval. The $\mathrm{O}_{3}$ profiles are retrieved from the $980-1100 \mathrm{~cm}^{-1}$ spectral 
(a)

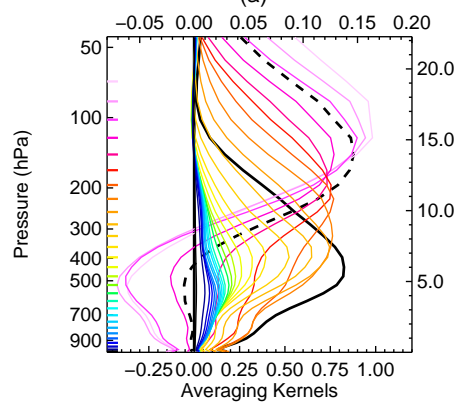

(b)

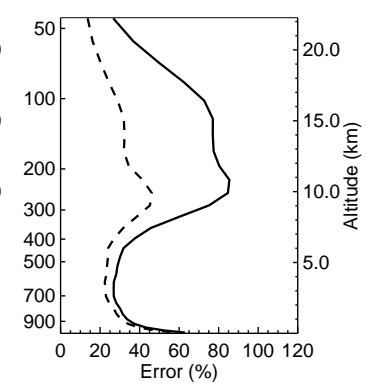

Fig. 2. Characterization of $\mathrm{O}_{3}$ retrievals based on 300 pixels recorded by IASI over the Arabian Sea $\left(15-20^{\circ} \mathrm{N}, 65-70^{\circ} \mathrm{E}\right)$ on 17/11/2008. (a) $\mathrm{O}_{3}$ averaging kernels (vertical resolution functions) for individual retrieval layers below $70 \mathrm{hPa}$ (color lines and upper $\mathrm{x}$ axis). The mean altitudes of the retrieval layers are the colored ticks on the left y-axis. Averaging kernels for integrated partial columns (lower x-axis) are given for the TOC (1013-225 hPa, black solid line) and the UTLS (225-70 hPa, black dashed line). (b) a priori $\mathrm{O}_{3}$ uncertainty (black solid line) and IASI $\mathrm{O}_{3}$ retrieval error (black dashed line).

window encompassing the $9.6 \mu \mathrm{m} \mathrm{O} 3$ absorption band. In order to avoid interferences, spectral regions with strong $\mathrm{H}_{2} \mathrm{O}$ absorptions are excluded. The IASI measurement noise covariance matrix set up in the 1D-Var scheme is based on an early pre-flight calibration (Ed Pavelin, private communication, 2011). This matrix is tridiagonal in order to take the correlation of radiometric noise between adjacent channels into account. The average noise computed from the diagonal elements of the covariance matrix in the $\mathrm{O}_{3}$ retrieval window is $28 \mathrm{nW}\left(\mathrm{cm}^{2} \mathrm{~cm}^{-1} \mathrm{str}\right)$. This value is close to the IASI radiometric noise estimated more recently to be of the order of $20 \mathrm{nW}\left(\mathrm{cm}^{-} 2 \mathrm{~cm}^{-1}\right.$ str) around $900 \mathrm{~cm}^{-1}$ in Clerbaux et al. (2009). Because the radiative transfer simulations are impacted by sources of error other than the radiometric noise (such as uncertainties on the temperature and water vapor profiles, the surface emisivity and, the spectroscopic parameters) the radiometric noise level used for the retrieval has to be taken conservatively. Based on sensitivity tests, we scale the noise covariance matrix from the 1D-Var scheme by a factor of 8 leading to a mean noise level of $80 \mathrm{nW}\left(\mathrm{cm}^{-} 2 \mathrm{~cm}^{-1} \mathrm{str}\right)$. This value is very close to $70 \mathrm{nW}\left(\mathrm{cm}^{-} 2 \mathrm{~cm}^{-1} \mathrm{str}\right)$, value used by Boynard et al. (2009) to retrieve $\mathrm{O}_{3}$ profiles from IASI with the Atmosphit LBL radiative transfer and retrieval algorithm.

The $\mathrm{O}_{3}$ retrievals are performed only for cloud free pixels or pixels weakly contaminated by clouds. The cloud filtering was performed according to Clerbaux et al. (2009), based on the AVHRR-derived fractional cloud cover from the IASI EUMETSAT L2 products. All pixels corresponding to a fractional cloud cover between 0 and $25 \%$ are processed. For pixels with unavailable cloud fraction, we use a cloud filter based upon retrieved surface temperature at 11 (T11) and 12 (T12) microns in a way comparable to what is done by Eremenko et al. (2009). When T12 is biased low by more than $10^{\circ} \mathrm{K}$ relative to the surface temperature from the ECMWF analyses, we remove the pixel as contaminated by a thick cloud. If $\mathrm{T} 11$ and $\mathrm{T} 12$ are differing by more than $10^{\circ} \mathrm{K}$, we remove the pixel as contaminated by a thin cloud.

The data that are described here correspond to the SOFRID $\mathrm{O}_{3}$ version 1.2 and are produced in HDF-EOS 5 files available on demand by email at the corresponding author.

\subsection{Characterization of the $\mathrm{O}_{3}$ retrievals}

Since our $\mathrm{O}_{3}$ inverse problem is not strongly non-linear, we can use the linear approximation for the characterization of the retrievals (Rodgers, 2000; Barret et al., 2005). For a linear retrieval, the retrieved state $\hat{\boldsymbol{x}}$ can be written as:

$\hat{\boldsymbol{x}}=\boldsymbol{x}_{a}+\mathbf{A}\left(\boldsymbol{x}-\boldsymbol{x}_{a}\right)+\mathbf{G}\left(\boldsymbol{\epsilon}+\boldsymbol{K}_{b}(\boldsymbol{b}-\hat{\boldsymbol{b}})\right)$

where $\boldsymbol{x}$ is the true state, $\boldsymbol{b}$ is the vector of the true model parameters (such as atmospheric temperature and water vapor, surface emissivity, spectroscopic parameters) and $\hat{\boldsymbol{b}}$ is the approximate of $\boldsymbol{b}$ available to the user. The Jacobian, $\boldsymbol{K}_{b}=\frac{\partial \boldsymbol{F}}{\partial \boldsymbol{b}}$, characterizes the sensitivity of the forward model $\boldsymbol{F}$ to the model parameters. The gain matrix, $\mathbf{G}$, is the matrix whose rows are the derivatives of the retrieved state with respect to the spectral points and $\epsilon$ is the measurement noise.

The averaging kernel matrix, $\mathbf{A}$, characterizes the sensitivity of the retrieved state to the true state. The element $\boldsymbol{A}(i, j)$ is the relative contribution of the element $\boldsymbol{x}(j)$ of the true state to the element $\hat{\boldsymbol{x}}(i)$ of the retrieved state. The vertical resolution of the retrieved profile can be defined as the Full Width at Half Maximum (FWHM) of the rows of the averaging kernel matrix. The number of independent elements of information contained in the measurement can also be estimated as the Degrees of Freedom for Signal (DFS) defined as the trace of the averaging kernel matrix (Rodgers, 2000).

IASI-SOFRID $\mathrm{O}_{3}$ averaging kernels representative of the south Asian region during the post-monsoon season are displayed in Fig. 2a for retrieval levels in the troposphere and UTLS (below $70 \mathrm{hPa}$ ). They correspond to the mean of the averaging kernels from hundreds of pixels recorded on the Arabian Sea on 17 November 2008. The DFS for this atmospheric layer is 1.7 meaning almost 2 independent pieces of information. With DFS of 0.78 and 0.9 , we can approximately attribute these pieces of information to the troposphere (Tropospheric Ozone Column (TOC), surface$225 \mathrm{hPa})$ and the UTLS $(225-70 \mathrm{hPa})$. The averaging kernels correponding to $\mathrm{O}_{3}$ partial columns for these two layers (see Fig. 2a) are clearly well separated with peaks at 500 and $150 \mathrm{hPa}$. The averaging kernels show that the sensitivity to the $\mathrm{O}_{3}$ content is the lowest in the lower troposphere below about $700 \mathrm{hPa}$. 
Table 1. Errors of IASI-SOFRID $\mathrm{O}_{3}$ columns.

\begin{tabular}{lccc}
\hline & $\begin{array}{c}\text { Pressure } \\
\text { boundaries }\end{array}$ & $\begin{array}{c}\text { a priori } \\
\text { error }(\%)\end{array}$ & $\begin{array}{c}\text { Retrieval } \\
\text { error }(\%)\end{array}$ \\
\hline Troposphere & $\begin{array}{c}\text { Surface-225 } \mathrm{hPa} \\
225-70 \mathrm{hPa}\end{array}$ & 33 & 15 \\
UTLS & 61 & 10 \\
\hline
\end{tabular}

From Eq. (1), it is easy to compute the retrieval error as the difference between the true and the retrieved states. The dominant source of error (Barret et al., 2005; Coheur et al., 2005; Boynard et al., 2009) is due to the smoothing of the true profile by the averaging kernel matrix accounting for the limited vertical resolution. The smoothing error covariance matrix is given by:

$\mathbf{S}_{s}=(\boldsymbol{A}-\boldsymbol{I}) \mathbf{S}_{a}(\boldsymbol{A}-\boldsymbol{I})^{T}$

The measurement error, $\boldsymbol{G} \boldsymbol{\epsilon}$, is due to the instrumental noise. Its covariance matrix is given by:

$\mathbf{S}_{m}=\mathbf{G S}_{\epsilon} \mathbf{G}^{T}$

where $\mathbf{S}_{\epsilon}$ is the noise covariance matrix. The sum of the smoothing and measurement errors is called the retrieval error (Rodgers, 2000). The remaining error is the model parameters error and accounts from uncertainties in the fixed model parameters.

The retrieval does not bring information below $900 \mathrm{hPa}$ where the retrieval error is almost equal to the a priori variability and brings maximum information between 400 and $50 \mathrm{hPa}$ (see Fig. 2b). These differences in vertical sensitivity, already shown with the averaging kernels, are partly due to the low (high) thermal contrast between the surface and the lowermost troposphere (UTLS). Concerning integrated columns, the reduction of uncertainty relative to the a priori is $\sim 2$. (resp. $\sim 6$ ) correponding to $15 \%$ (resp. $10 \%$ ) error for the TOC (resp. UTLS) (Table 1).

\subsection{Validation of the $\mathrm{O}_{3}$ profiles}

This section is dedicated to the validation of IASI-SOFRID $\mathrm{O}_{3}$ retrievals from the troposphere to the UTLS. We have used WOUDC and SHADOZ profiles from the database described above (Sect. 2.2) for the period July-December 2008. We have used coincidence criteria of $\pm 1^{\circ}$ and $\pm 12 \mathrm{~h}$ for the comparisons between IASI and sonde data. These criteria are identical to the ones used by Keim et al. (2009) who have validated IASI preliminary tropospheric $\mathrm{O}_{3}$ products. MOZAIC profiles measured at take-off and landing near Hyderabad $\left(17.2^{\circ} \mathrm{N}, 78.3^{\circ} \mathrm{E}\right)$ during the same period are also used to demonstrate the ability of IASI to capture the tropospheric $\mathrm{O}_{3}$ variability over Central India. Because MOZAIC profiles are limited to roughly $220-250 \mathrm{hPa}$, they cannot be used for validating IASI UTLS columns. The aircraft is traveling about $400 \mathrm{~km}$ between the ground and its flight altitude at takeoff and landing. We have therefore used a relaxed spatial coincidence criterion of $1.5^{\circ}$ around the position of the aircraft half way of its ascent or descent (about $200 \mathrm{~km}$ from Hyderabad) for comparisons of IASI and MOZAIC. The MOZAIC data from Hyderabad are further used in details to help characterize the tropospheric $\mathrm{O}_{3}$ post-monsoon intra-seasonal variabilty in Sect. 3.4.

Raw comparison between in situ and IASI data are important because they allow us to evaluate the real quality of the retrieved $\mathrm{O}_{3}$ data. In order to remove the intrinsic impact of smoothing and a priori data and to perform more meaningful comparisons, the high resolution validation profiles, $\boldsymbol{x}_{\mathrm{vl}}$, have to be smoothed with the averaging kernels matrix of the low resolution IASI retrievals according to Rodgers (2000):

$\boldsymbol{x}_{\mathrm{vl} \text { Smoothed }}=\boldsymbol{x}_{a}+\boldsymbol{A}\left(\boldsymbol{x}_{\mathrm{vl}}-\boldsymbol{x}_{a}\right)$

where $\boldsymbol{x}_{\mathrm{vl}}\left(\boldsymbol{x}_{\mathrm{vl}}\right.$ Smoothed $)$ is the raw (smoothed) $\mathrm{O}_{3}$ validation profile. As can be understood from Eq. (4), the validation profile has to cover the whole retrieval altitude range from the ground up to $10 \mathrm{hPa}$. As mentioned above (Sect. 2.2), the $\mathrm{O}_{3}$ profiles from our database are based on in situ radiosonde and MOZAIC profiles completed by coincident MLS assimilated data above their uppermost altitudes. The comparisons of IASI and sonde data performed for July-December 2008 are presented for both high (poleward of $40^{\circ}$ ) and low (equatorward of $40^{\circ}$ ) latitudes in Fig. 3 for profiles and in Fig. 4 and Table 2 for integrated columns. Comparisons of TOC (below $250 \mathrm{hPa}$ ) from IASI and MOZAIC near Hyderabad are presented in Fig. 5 and Table 2. For both high and low latitudes, absolute biases between IASI and $\mathrm{O}_{3}$ raw sonde data are mostly within $\pm 30 \%$ with Relative Standard Deviations (RSDs) of the differences between 20 and $60 \%$. At low latitudes, the a priori weighted towards mid-latitude combined with the low sensitivity of IASI to lower tropospheric $\mathrm{O}_{3}$ are responsible for the high bias below $700 \mathrm{hPa}$ (Fig. 3e). The bias is therefore largely removed when the sonde profiles are smoothed using Eq. (4) (Fig. 3f). The retrievals are able to obtain realistically low $\mathrm{O}_{3}$ in the tropical UTLS where the differences relative to the a priori are the highest. This result supports the use of a retrieval method based on the linearization of the radiative transfer model. The RSD profile for high latitudes is very similar to the retrieval error profile displayed in Fig. 2 with a maximum around the tropopause, validating the error analysis provided in Sect. 2.3. For low latitudes, the RSD is higher than for high latitudes especially between 300 and $100 \mathrm{hPa}$. This difference in RSDs is mostly due to the reduction of the $\mathrm{O}_{3}$ mixing ratios by factors ranging from 2 to 3 at low relative to high latitudes.

Concerning the TOC and UTLS column (Table 2), the RSDs from the differences between raw sonde and IASI data are ranging from $\sim 15 \%$ at high latitudes to $\sim 23 \%$ at low latitudes in good agreement with the retrieval errors from 
(a) $\mathrm{O}$ profiles high-latitudes

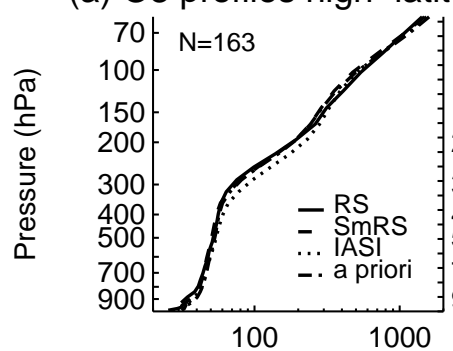

(d) O3 profiles low-latitudes

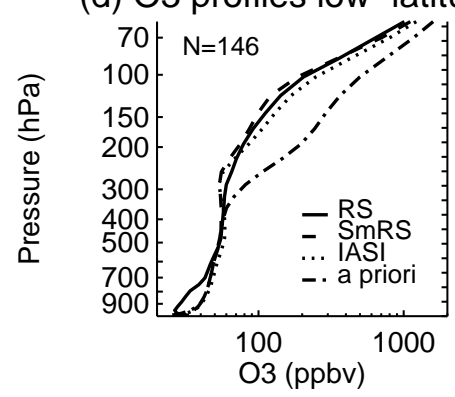

(b)

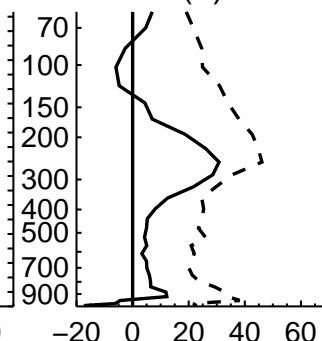

(e) (c)

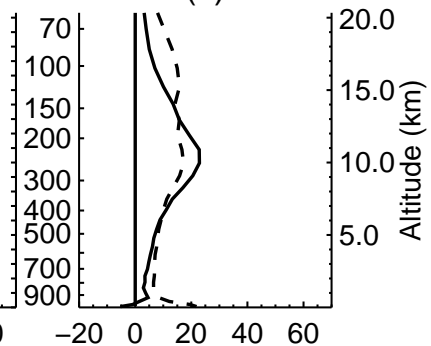

(f)

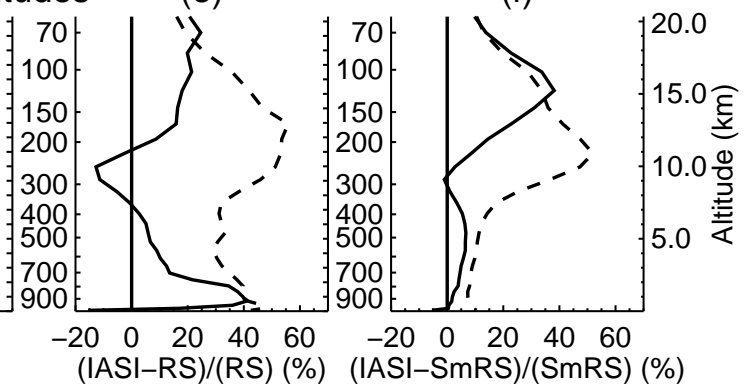

Fig. 3. Statistical comparison between $\mathrm{O}_{3}$ profiles retrieved from IASI and coincident $\left( \pm 1^{\circ}, \pm 12 \mathrm{~h}\right)$ sonde profiles for July-December 2008 . (a) Mean profiles for high latitudes $\left[90^{\circ} \mathrm{S}-40^{\circ} \mathrm{S}, 40^{\circ} \mathrm{N}-90^{\circ} \mathrm{N}\right.$ ] (solid line) sonde, (dashed line) sonde convolved with IASI Averaging Kernels (Eq. 4), (dotted line) IASI retrieval (dashed-dotted line) IASI a priori profile. (b) Statistics for high latitudes profiles for raw ozonesonde data (black solid lines) mean differences (black dashed lines) RSD. (c) Same as (b) for ozonesonde data convolved with IASI averaging kernels according to Eqs. 4. (d) (e) and (f) Same as (a) (b) and (c) for low latitudes $\left[40^{\circ} \mathrm{S}-40^{\circ} \mathrm{N}\right]$.

Table 2. Validation of IASI-SOFRID $\mathrm{O}_{3}$ columns with global ozonesonde data and MOZAIC data from Hyderabad during July-December 2008 for the troposphere (ground-225 hPa for ozonesondes and ground-250 hPa for MOZAIC) and the UTLS (225-70 hPa).

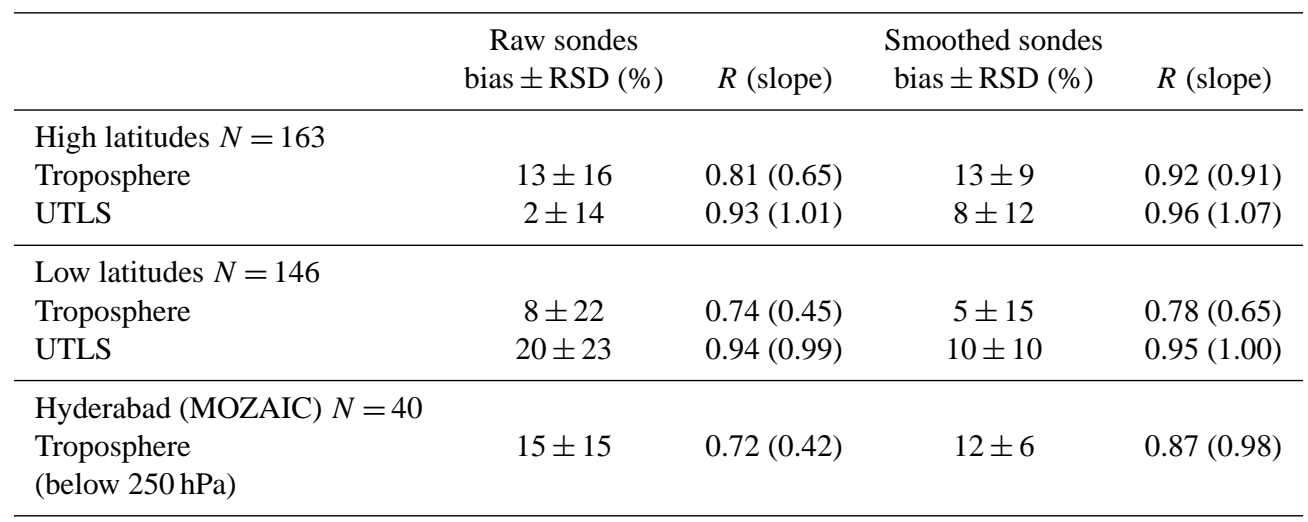

Sect. 2.3. The IASI $\mathrm{O}_{3}$ TOC and UTLS columns are biased high relative to raw sonde with biases ranging from $2 \%$ for high latitudes UTLS to $20 \%$ for low latitudes UTLS. This difference is again due to the difference in UTLS $\mathrm{O}_{3}$ concentrations between high and low latitudes. For UTLS $\mathrm{O}_{3}$ partial columns (Table 2), little difference is found between low and high latitudes and between raw and smoothed ozonesonde data with correlation coefficients and slopes close to unity (see Fig. 4a and b), highlighting the high sensitivity of IASI to this atmospheric layer. For the TOC, sonde versus IASI agreement is still good ( $R>0.74$, see Fig. $4 \mathrm{c}$ and d), but the lower correlation coefficients and slopes for low versus high latitudes and for raw versus smoothed sonde data result from the lower sensitivity of IASI to the lower troposphere.

The variations of TOC near Hyderabad from July to December measured by MOZAIC (14-32 DU, Fig. 5a) 

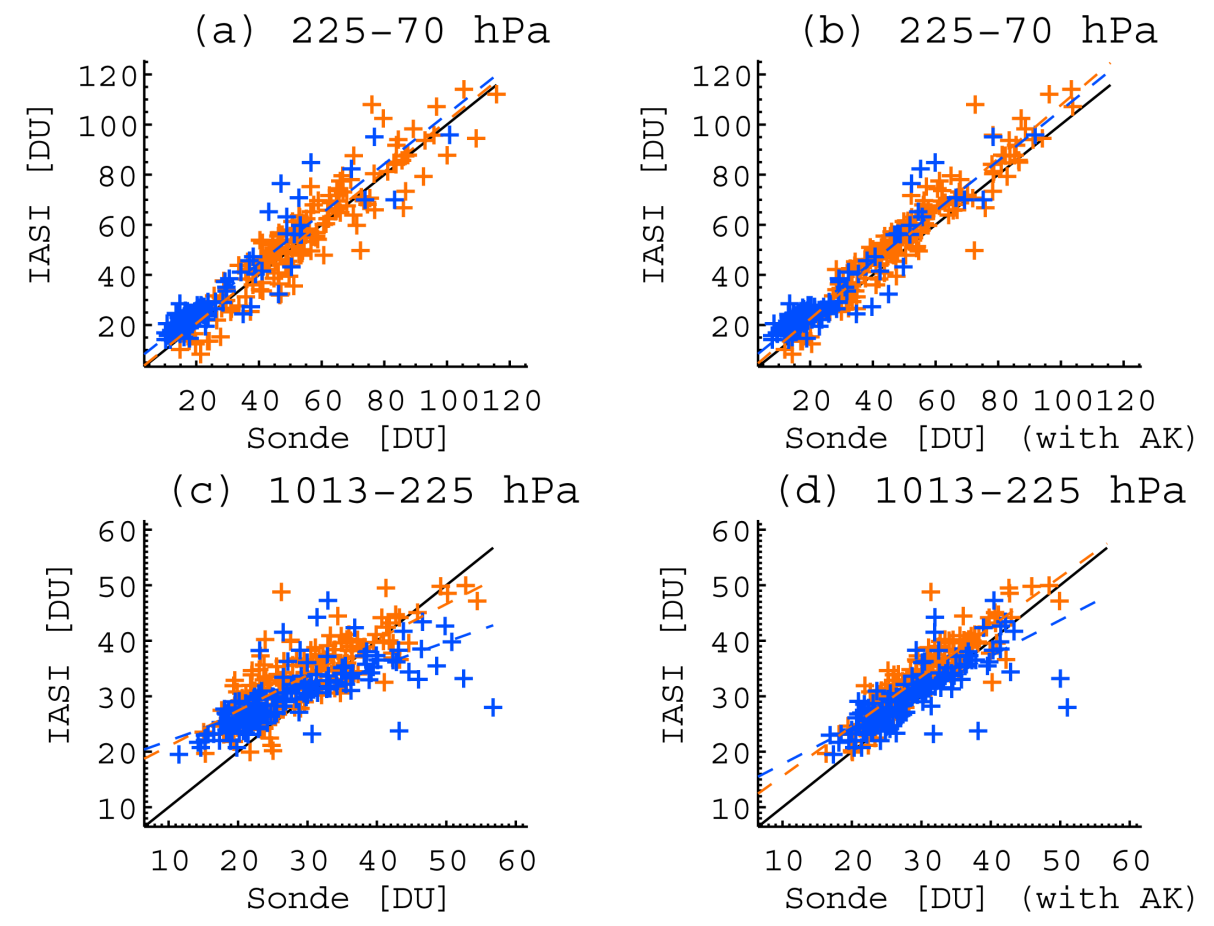

Fig. 4. Correlation plots between $\mathrm{O}_{3}$ columns retrieved from IASI and computed from coincident sonde profiles for July-December 2008 . (a) UTLS columns. (b) UTLS columns with sonde profiles convolved with IASI Averaging Kernels. (c) Same as (a) for TOC. (d) Same as (c) for TOC. (blue) low latitudes (orange) high latitudes.
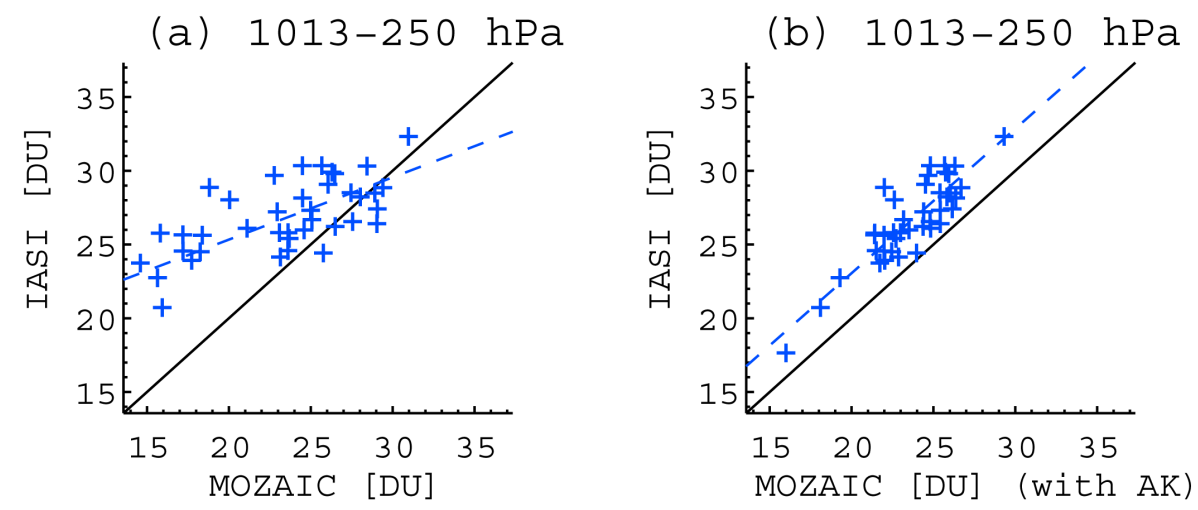

Fig. 5. Correlation plots between TOC (below $250 \mathrm{hPa}$ ) computed from MOZAIC profiles near Hyderabad and retrieved from IASI coincident $\left( \pm 1.5^{\circ}, \pm 12 \mathrm{~h}\right.$ ) pixels for Jul.-Dec. 2008. (a) TOC from raw MOZAIC data (b) TOC from MOZAIC profiles completed above flight altitude by MLS data (see text for details) and convolved with IASI Averaging Kernels.

represent only one third of the variations measured by ozonesondes at low latitudes (10-60 DU, Fig. 4c). Nevertheless, IASI data are in good agreement with raw MOZAIC data near Hyderabad with a similar correlation coefficient and a similar slope than for the comparison with sonde data at low latitudes (Table 2). Once the validation profiles are smoothed by the averaging kernels the correlation coefficient and the slope become very close to unity (Fig. 5b) highligth- ing the ability of IASI to capture TOC variability over central India. The positive bias of IASI is twice larger for Hyderabad than for the global low latitudes and is comparable to the high latitudes bias. A possible explanation of this difference is that the highest bias at low latitudes correspond to the lowest TOC values (below $30 \mathrm{DU}$, see Fig. 4c) which are comparable to the TOC values measured by MOZAIC near Hyderabad. 


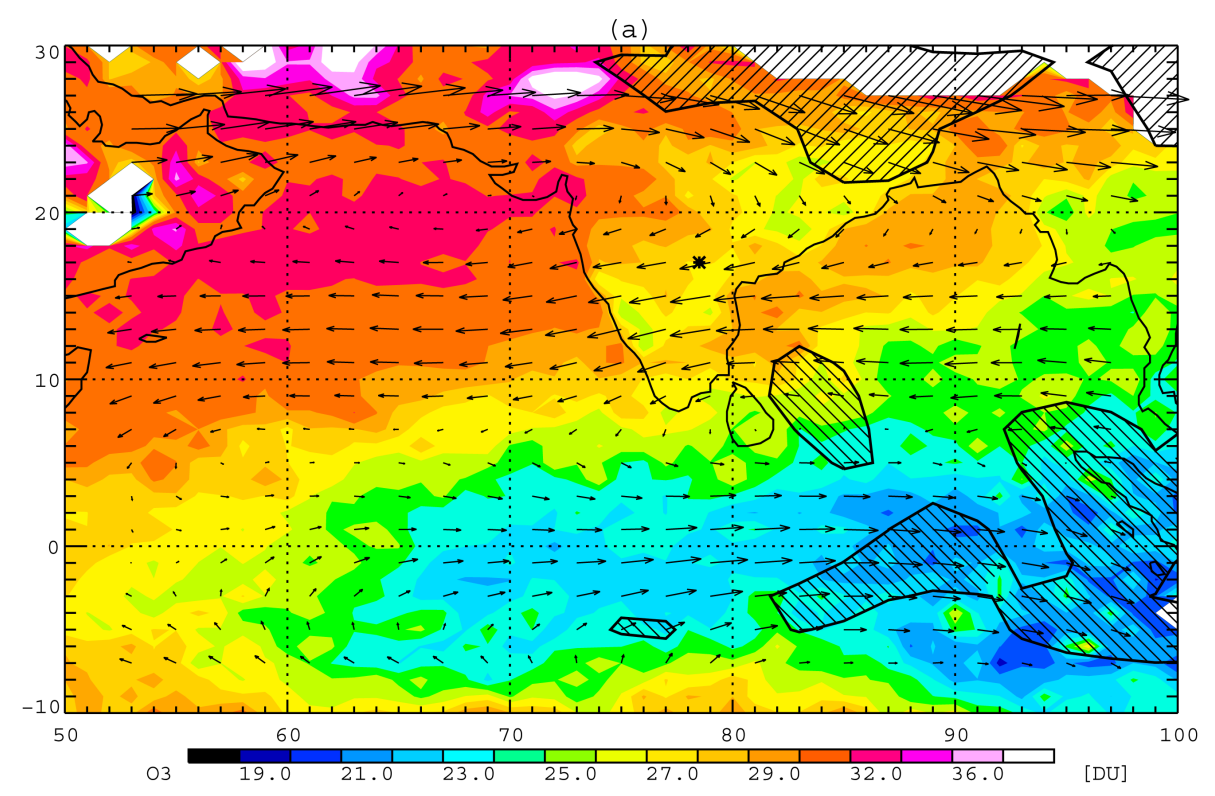

Fig. 6. Monthly (November 2008) IASI-SOFRID O 3 tropospheric (surface-225 hPa) columns. Monthly (November 2008) horizontal winds from Arpege averaged over 500-650 hPa are represented as black arrows and 500-650 hPa averaged vertical velocities in pressure coordinate are represented as black contours hatched black at (i) $45^{\circ}$ clockwise for descent $\left(\omega<-0.075 \mathrm{~Pa} \mathrm{~s}^{-1}\right)$ (ii) $45^{\circ}$ anticlockwise for ascent $\left(\omega>0.075 \mathrm{~Pa} \mathrm{~s}^{-1}\right)$. The location of Hyderabad is represented by a black asterisk. White areas are for missing data.

\section{Post-monsoon tropospheric $\mathrm{O}_{3}$ variability over South Asia in 2008}

In this section, we will first examine post-monsoon $\mathrm{O}_{3}$ variations observed by MOZAIC near Hyderabad in central India. Based on wind field analyses and lagrangian modeling we will highlight the importance of transport and weather conditions in controlling the observed tropospheric $\mathrm{O}_{3}$ variations. We will then point out the benefit of $\mathrm{IASI}_{3}$ data to characterize the variations of $\mathrm{O}_{3}$ over the whole south Asian region. We first give a brief description of the post-monsoon tropospheric circulation and $\mathrm{O}_{3}$ distribution in November 2008.

\subsection{Post-monsoon circulation and mean November 2008 $\mathrm{O}_{3}$ distribution}

The withdrawal of the summer monsoon occurs rapidly from September to early October and by November the wind fields are similar as during the rest of the winter season (Lawrence and Lelieveld, 2010). From September to December, the Inter Tropical Convergence Zone (ITCZ) migrates from India where it was located during the summer monsoon to the equatorial eastern Indian Ocean. During the winter season, the lower tropospheric circulation over the Northern Indian Ocean is dominated by northeasterly trades. Large-scale subsidence over the continental source regions prevents upward dispersion of pollutants (Lelieveld et al., 2001). The mid-tropospheric circulation for November 2008 is displayed in Fig. 6. It corresponds to the description of the Asian monsoon autumn by Barry and Chorley (1995). After the summer monsoon circulation break-up, Pacific easterlies at $500 \mathrm{hPa}$ affect the Bay of Bengal and monsoon westerlies are established over the Equator. In October, the Subtropical Westerly Jet (SWJ) migrates south of the Tibetan plateau and the cool season starts over most of southern and eastern Asia. The area of high pressure, cold temperature and subsidence (see vertical velocities in Fig. 6) over northern India is connected to the monsoon convection and its associated ascending velocities (Fig. 6) over the equatorial eastern Indian ocean by the lateral monsoon circulation (de Laat and Lelieveld, 2002).

During the post-monsoon season (November 2008), the distribution of TOC observed by IASI over south Asia (Fig. 6) is characterized by a strong SE-NW gradient with values of 20-25 DU over the equatorial Indian Ocean rising to 30-36 DU over the Arabian Sea. This $\mathrm{O}_{3}$ distribution clearly results from the mean circulation. Mid tropospheric $\mathrm{O}_{3}$-rich air masses are trapped within the anticyclone bounded by the westerly jet and the easterly trades over the Arabian Sea and northern India. Low $\mathrm{O}_{3}$ concentrations are associated with the equatorial westerly monsoon flow bringing pristine air from the western Indian Ocean towards Indonesia. The $\mathrm{CO}$ and $\mathrm{O}_{3}$ latitudinal gradient observed during INDOEX also highlighted the role of the ITCZ as a barrier for mixing between clean maritime air masses from the southern Indian ocean and polluted air masses from the northern hemisphere (Stehr et al., 2002). 


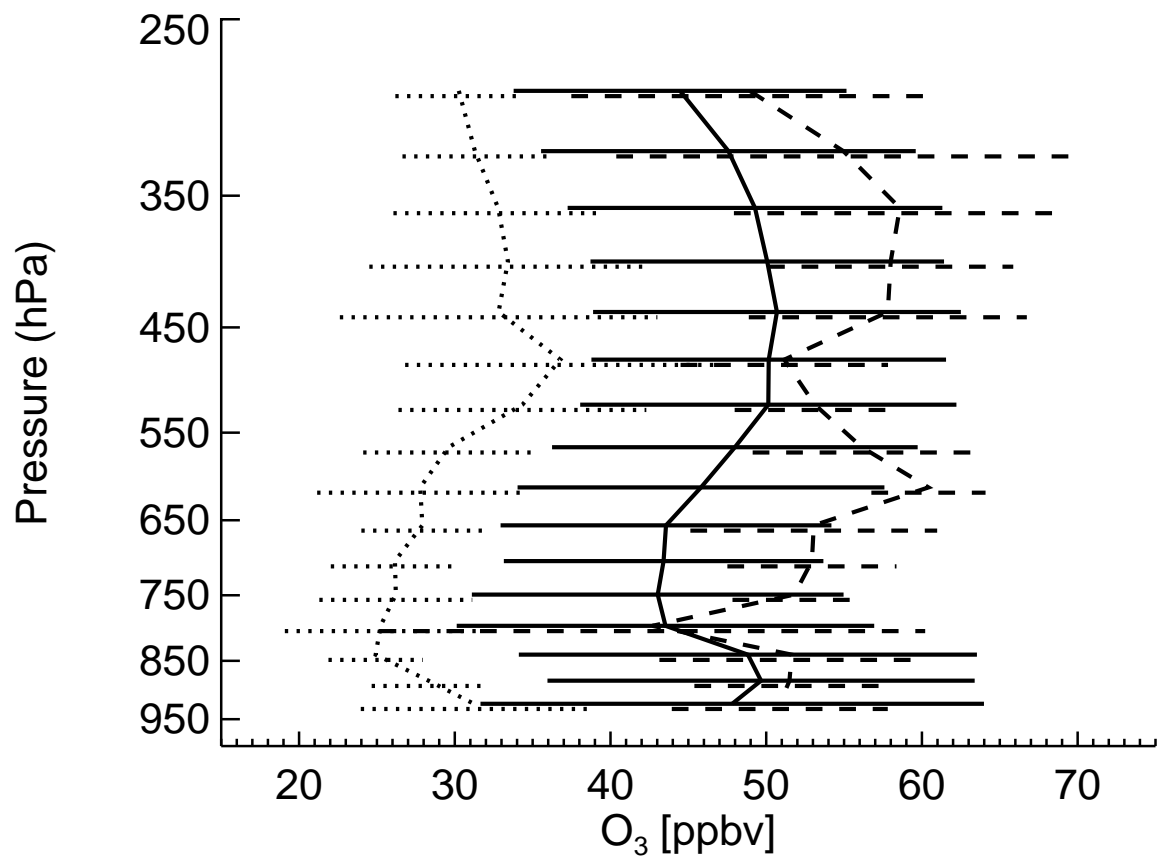

Fig. 7. $\mathrm{O}_{3}$ tropospheric profiles from MOZAIC during landing and take-off at Hyderabad: (solid line) October to December mean profile. (Dashed line) 9-13 and 23-26 November average corresponding to high ozone conditions .(Dotted line) 16-19 19-27 November average corresponding to low ozone conditions. Error bars correspond to $1 \sigma$ standard deviations.

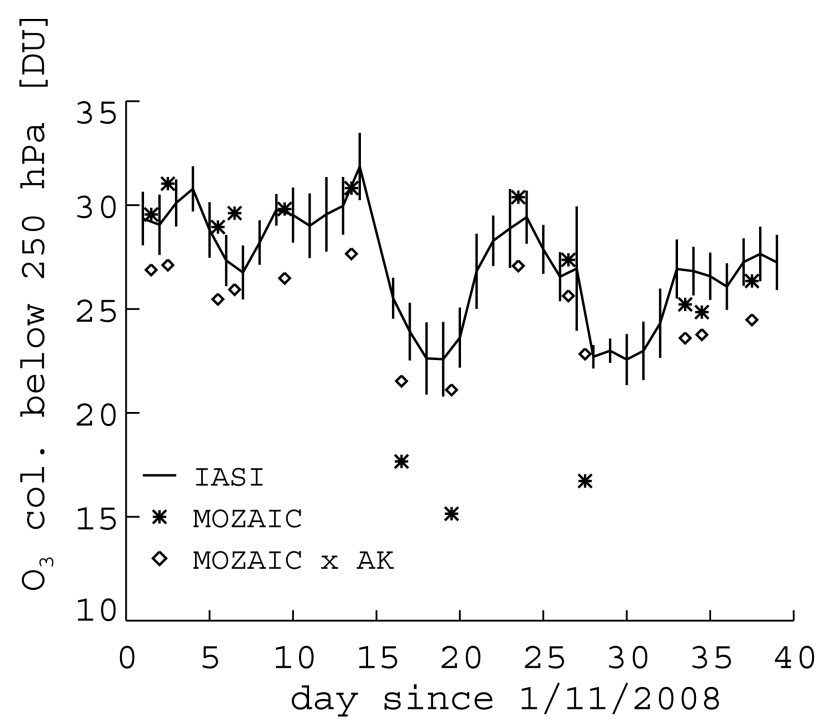

Fig. 8. Time series of $\mathrm{O}_{3}$ tropospheric (surface- $250 \mathrm{hPa}$ ) columns near Hyderabad from 1 November 2008 until 10 December 2008 from (asterisque) MOZAIC (diamonds) MOZAIC convolved with IASI Averaging Kernels (solid line) IASI-SOFRID coincident $\left( \pm 1.5^{\circ}, \pm 12 \mathrm{~h}\right)$ pixels. Error bars correspond to IASI $1 \sigma$ standard deviations.

\subsection{Observed $\mathrm{O}_{3}$ variability near Hyderabad: MOZAIC data}

Only a few studies have characterized the tropospheric $\mathrm{O}_{3}$ distribution over India especially during the post-summer monsoon period. Mean data from 6 radiosondes launched from Kanpur in northern India $\left(26^{\circ} \mathrm{N}, 80^{\circ} \mathrm{E}\right)$ in December 2004 (Gupta et al., 2007) give evidence of almost constant tropospheric $\mathrm{O}_{3}$ with mixing ratios around $50 \mathrm{ppbv}$ throughout the troposphere. Based on MOZAIC aircraft data for 1996-2001, Sahu et al. (2009) determined the seasonal variations of tropospheric $\mathrm{O}_{3}$ over Dehli $\left(28.6^{\circ} \mathrm{N}, 77.1^{\circ} \mathrm{E}\right)$. For the October-December season, the mean $\mathrm{O}_{3}$ profile over Delhi shows little vertical variability in the mid-troposphere with mixing ratios between 50 and $60 \mathrm{ppbv}$.

The MOZAIC data measured after take-off and before landing at Hyderabad represent a unique source to document tropospheric $\mathrm{O}_{3}$ over central India. The mean postmonsoon (October-December 2008) $\mathrm{O}_{3}$ profile computed from MOZAIC data over Hyderabad displayed in Fig. 7 is in good agreement with Sahu et al. (2009) and Gupta et al. (2007) with mixing ratios between 45 and 50 ppbv below $300 \mathrm{hPa}$. Figure 8 presents the TOC derived from the MOZAIC data from 1 November until 10 December 2008. During this period, tropospheric $\mathrm{O}_{3}$ varies from $30 \mathrm{DU}(9$ and 13 November) to less than 15 DU (19 and 27 November). In order to characterize the vertical extent of these variations, 
(a)

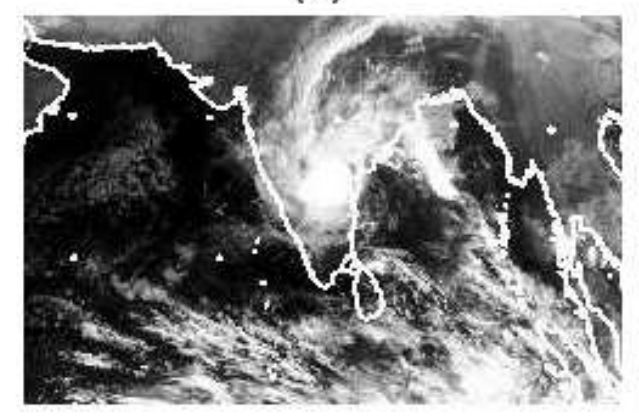

(b)

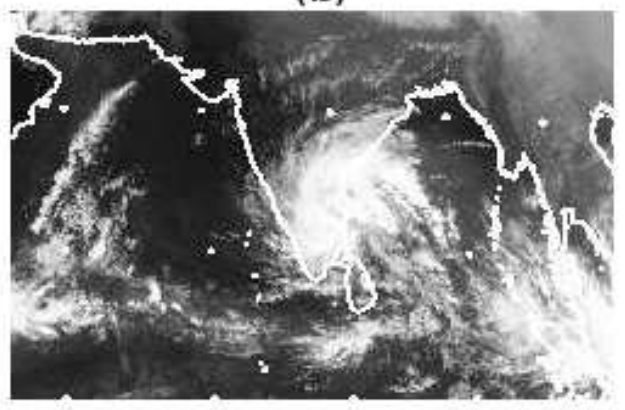

Fig. 9. METEOSAT-7 images of November 2008 storms over India: (a) storm Khai-Muk on 16 November at 00:00 GMT, (b) storm Nisha on 27 November at 12:00 GMT.
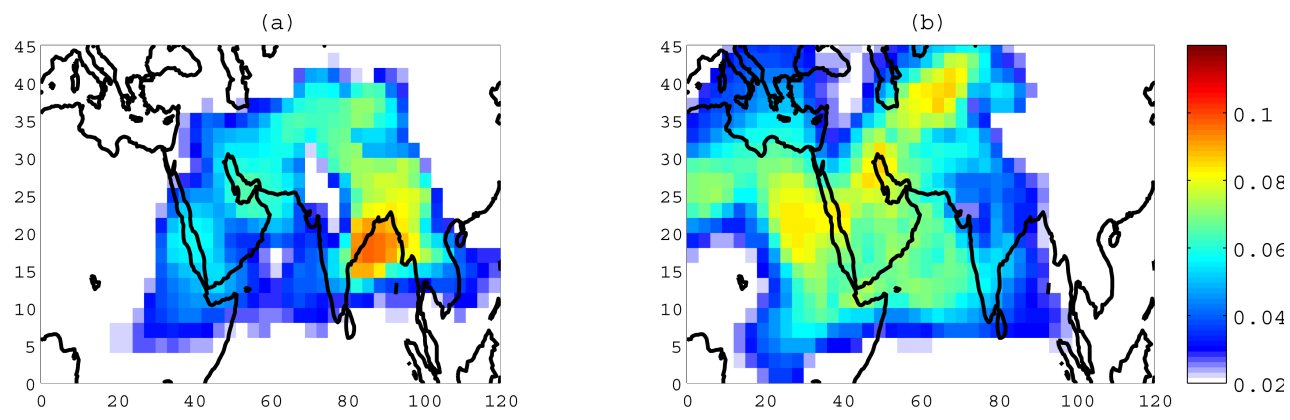

Fig. 10. FLEXPART retroplume mean residence time fraction (MRTF, in \%) for particles reaching the mid-troposphere (4000-6000 $\mathrm{m}$ a.g.1.) over Hyderabad on 11 November for layers: (a) BL (0-3 km) (b) UT (8-15 km).

Fig. 7 displays mean MOZAIC $\mathrm{O}_{3}$ profiles for periods of elevated $(9,13,23$ and 26 November) and low (16, 19 and 27 November) TOC. For the low $\mathrm{O}_{3}$ period, the decrease of $\mathrm{O}_{3}$ relative to the mean post-monsoon profile (15-20 ppbv) is significant within the whole sampled vertical range. As can be seen from Fig. 7, the profile corresponding to periods of elevated $\mathrm{O}_{3}$ during November-December. is closer to the post-monsoon mean profile with increases of $\sim 10 \mathrm{ppbv}$.

The question arising from MOZAIC observations is: what causes a factor of 2 variation in the tropospheric $\mathrm{O}_{3}$ concentration over central India within a couple of days? A detailed analysis of the regional weather conditions and of air-mass transport pathways presented in Sect. 3.3 will help to address this question.

\section{3 $\mathrm{O}_{3}$ weather relationship over Hyderabad}

The severe and fast drops of $\mathrm{O}_{3}$ concentration affecting the whole troposphere over Hyderabad as observed with MOZAIC must be correlated to dramatic changes of the tropospheric circulation. In October-November, the confluence between easterlies at $500 \mathrm{hPa}$ and equatorial westerlies gen- erate disturbances resulting in the formation of major storms over the Bay of Bengal and maximum rainfall in south-east India (Barry and Chorley, 1995). Examining weather forecast information and satellite cloud images, we found that in November 2008, India was hit by two particularly strong cyclonic storms.

The Khai Muk storm built up over the Bay of Bengal on 15 November 2008 and moved north/north westward towards India. It came inland over the state of Andrah Pradesh during the night and became a deep depression on 16 November (see Fig. 9a). The strong rainfalls caused by the storm between Guntur and Vishakhapatnam were responsible for the destruction of crop fields and the displacement of thousands of inhabitants. Cyclone Khai-Muk weakened rapidly once encountering land, and only a remnant cyclonic circulation managed to cross the peninsular landmass and slide into the Arabian Sea off the Karnataka-Goa coasts on 17 November. We see in Fig. 8 that the TOC dropped near Hyderabad the first time on 17 November just after the crossing of KhaiMuk over Andrah Pradesh. 


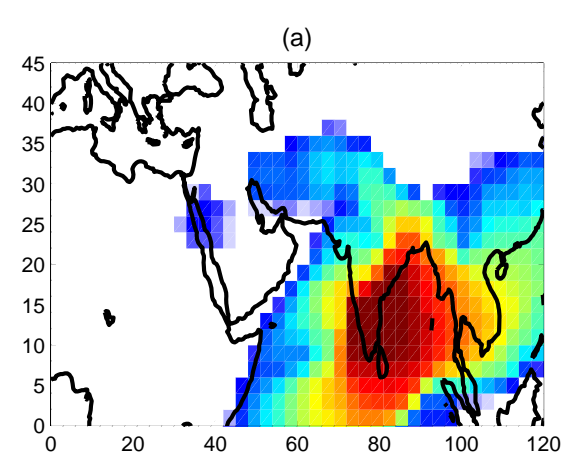

Fig. 11. Same as Fig. 10 for 29 November.

A depression formed over Sri Lanka on November 25 and intensified into a cyclonic storm called Nisha on 26 November close to the coast of Tamil Nadu. It caused heavy rains, floods and hundreds of death in Tamil Nadu. Nisha crossed the coast close to Karaikal in south-east India in the early morning of 27 November and headed northwest towards the Karnataka state (see Fig. 9b). Here again, the strong drop in $\mathrm{O}_{3}$ near Hyderabad on 27 November follows the crossing of Nisha.

In order to determine long range and meso-scale transport pathways as well as geographical regions influencing MOZAIC $\mathrm{O}_{3}$ observations, we use simulations with the FLEXPART Lagrangian particle dispersion model (version 6.2) (Stohl et al., 1998, 2005). FLEXPART enables to establish a relationship between a source which may be a region characterized by pollutant emissions and a receptor which may be a location impacted by these emissions. A large number of particles is released from the receptor location and transported backward in time. FLEXPART outputs the residence time of all the particles which is a fourdimensional variable that represents the sensitivity of the source to the receptor. In our simulation, the residence time is output every $6 \mathrm{~h}$ of integration on a uniform grid of $2^{\circ}$ latitude $\times 3^{\circ}$ longitude and in 22 vertical layers. Because the relative values of residence time are more meaningful than the absolute values (that depends on the number of particles released), we use the mean residence time fraction (MRTF) to describe the transport pathways highlighted by FLEXPART simulations. For each gridcell, this variable is computed as the residence time integrated over the whole simulation period, divided by the residence time integrated over the global domain and also over the whole simulation.

The model is driven by ECMWF wind fields with a temporal resolution of $3 \mathrm{~h}$, with $0.3 \times 0.3^{\circ}$ horizontal resolution and 91 vertical levels. FLEXPART parameterizes turbulence by solving Langevin equations (Stohl and Thomson , 1999), and uses the parameterization scheme of Emanuel and ZivkovicRothman (1999) to describe all types of convection. Vertical transport of air-masses result from the combination of large-

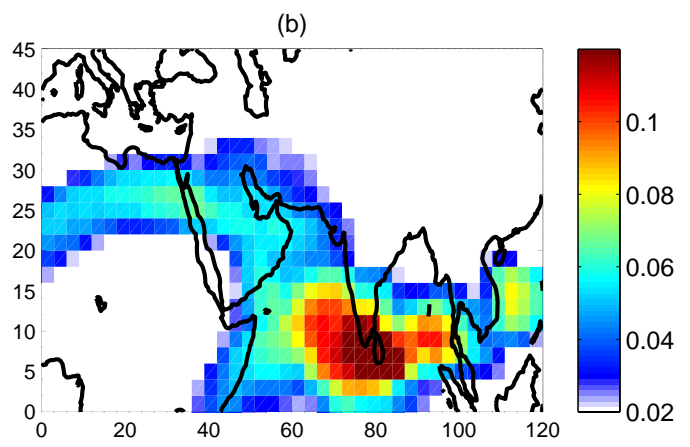

scale advection by the ECMWF winds and vertical mixing by the mass-fluxes computed by the convective scheme.

We used FLEXPART to make 10 days backward simulations with $1 \mathrm{M}$ particles released from 3-D boxes between 4000 and $6000 \mathrm{~m}$ above ground level (a.g.l.) around Hyderabad. Simulations performed with 3 -D boxes of $0.5^{\circ}$ and $3^{\circ}$ around Hyderabad give very similar results. In the following, we discuss results from simulations with $3^{\circ} 3-\mathrm{D}$ boxes. In order to synthesize the results of the FLEXPART runs, we show the results in only 2 layers : the Boundary Layer (BL) $0-3 \mathrm{~km}$ and the Upper Troposphere (UT) $8-15 \mathrm{~km}$. Figures 10 and 11 display the MRTF integrated over these two layers, for 11 and 29 November, respectively.

Based on the variations observed by MOZAIC and IASI (Fig. 8) we investigated 4 cases corresponding to high and low tropospheric $\mathrm{O}_{3}$ over central India.

The first case, 11 November, corresponds to conditions close to the mean November conditions with high TOC observed near Hyderabad by MOZAIC and by IASI from 9 to 15 November (Fig. 8). The MRTFs in the two layers defined above are displayed in Fig. 10. An important fraction of the particles reaching the middle troposphere over Hyderabad have spent some time in the BL over the Indo-Gangetic plain within the 10 days prior to their arrival (Fig. 10a). They followed the low-level anticyclonic circulation which is ending with the northeasterly trades flowing from the Bay of Bengal towards Hyderabad. BL air masses from the highly populated and polluted Indo-gangetic plain are loaded with $\mathrm{O}_{3}$ precursors and partly responsible for enhanced $\mathrm{O}_{3}$ concentrations in the mid-troposphere at Hyderabad. Based upon observations over the Indian Ocean, studies performed within the INDOEX project (see e.g. Lawrence and Lelieveld, 2010; Lelieveld et al., 2001; Verver et al., 2001) have shown that this transport pathway contributed to the Indian continental outflow over the Bay of Bengal and the Indian Ocean during the winter season. The results presented here, based upon MOZAIC observations at Hyderabad, complement INDOEX in showing that this transport pathway also impact the tropospheric composition over central India. Air masses from the 
(a)

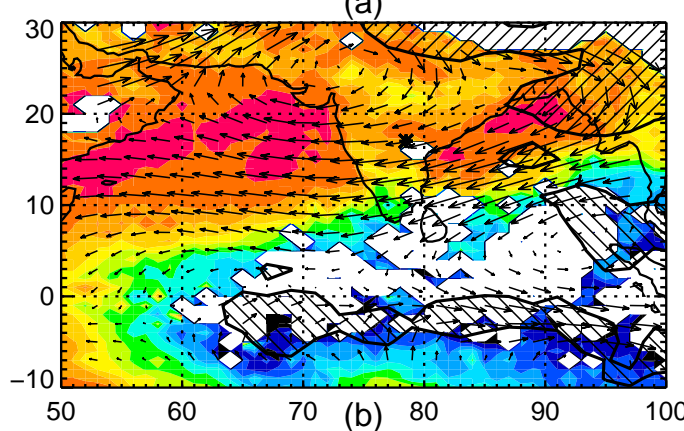

(c)

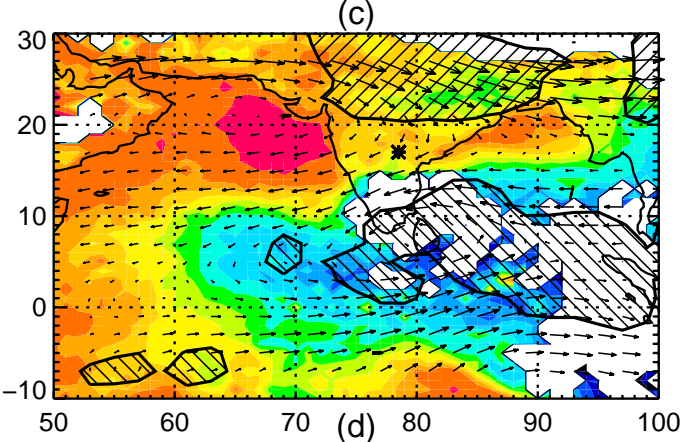

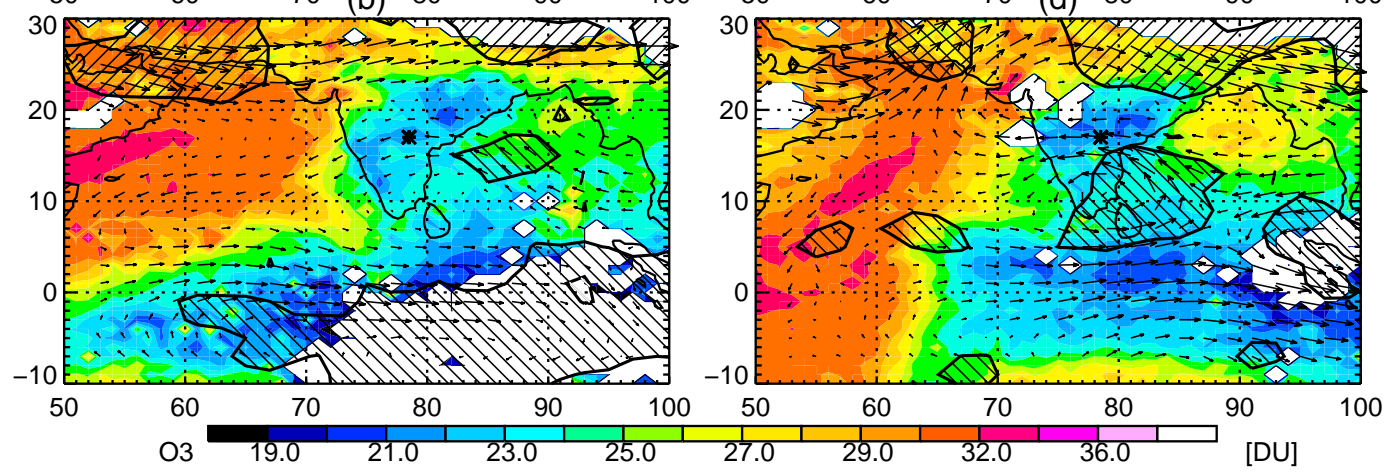

Fig. 12. Same as Fig. 6 for (a) 10-12 November 2008, (b) 16-18 November 2008, (c) 24-26 November 2008, (d) 28-30 November 2008. The Arpege winds presented correpsond to averages for the 5 days prior to the middle day of the 4 periods. White areas are for missing data.

UT are transported eastward following the SWJ and are subsiding over the cold regions of northern India before reaching Hyderabad. During 1-11 November, the SWJ is undulating around its main position at $25^{\circ} \mathrm{N}$, with an excursion above the eastern Mediterranean and a large wave over central Asia (not shown). As a consequence, $\mathrm{O}_{3}$-rich air masses originating from the Mediterranean and central Asian mid-latitude UTLS are reaching the mid-troposphere at Hyderabad on 11 November as can be seen on Fig. 10b. The global integration of the MRTFs shows that the UT/UTLS is contributing more $(42 \%)$ to the air masses reaching the middle troposphere around Hyderabad on 11 November than the BL (24\%) further highlighting the importance of the UTLS in controling the high $\mathrm{O}_{3}$ concentrations over south Asia in winter. FLEXPART simulations for 25 November (not shown) characterized by similar TOC over Hyderabad also show air masses coming eastward from the UTLS along the SWJ.

Before 25 November, the circulation has been strongly perturbed by the crossing of Khai-Muk with in particular the suppression of the northeasterly trades over the Bay of Bengal and no air masses are coming from the Indian BL to Hyderabad on 25 November.

The third case, 29 November, corresponds to the situation left after tropical storm Nisha crossed over India. The crossing of the storm resulted in large-scale modifications of the circulation over south Asia. As can be seen in Fig. 11, air masses from the BL are travelling from the Bay of Bengal and the Indian Ocean following the storm track and UT air masses are mostly originating from the Indian Ocean south of India. The uplift of pristine air-masses from the Marine Boundary Layer (MBL) to the mid-troposphere within the storm results in the large decrease in tropospheric $\mathrm{O}_{3}$ near Hyderabad. Moreover, UT air masses from the Indian Ocean are poor in $\mathrm{O}_{3}$ relative to mid-latitude UTLS air-masses, and their north-westward transport is also contributing to the decrease in $\mathrm{O}_{3}$ over Hyderabad. Contrary to what has been shown for 11 November, on 29 November the global BL contribution (37\%) is higher than the global UT contribution (32\%) further demonstrating the large impact of the MBL's airmass transport upon the drop of $\mathrm{O}_{3}$ at Hyderabad. The last case (not shown) corresponds to 17 November, characterized by low TOC over Hyderabad after tropical storm Khai-Muk crossed over India. The results are very similar to those of 29 November, with air masses mostly coming from the MBL of the Bay of Bengal.

This analysis has led us to the following questions: does the variability determined from the MOZAIC data extend over a large region? Is IASI able to capture the fast variations of tropospheric $\mathrm{O}_{3}$ at the continental scale? We now present our IASI $\mathrm{O}_{3}$ data that will provide answers to those questions. 


\section{$3.4 \mathrm{O}_{3}$ variability over the Indian region: IASI data}

The comparison of TOC measured by IASI and MOZAIC over Hyderabad during the studied period is displayed in Fig. 8. As already shown in Sect. 2 for the July-December period, the agreement between IASI and MOZAIC raw data is better for high than for low TOC that are overestimated by IASI. Figure 8 highlights an excellent agreement between IASI and MOZAIC after smoothing of the validation profiles with the averaging kernels as was demonstrated in Sect. 2. It is noteworthy that IASI is able to capture the fast variability of $\mathrm{O}_{3}$ and particularly the sharp drops of TOC from 14 to 16 and from 27 to 29 November with amplitudes very close to those observed by MOZAIC smoothed with the averaging kernels. The variations measured by both instruments on both occasions, which range from 12 to $26 \%$, are much larger than the $6 \%$ RMS of the differences between the two datasets (see Table 2). Based on the time series from Fig. 8 we have focused our attention on periods corresponding to low (16-18 and 28-30 November) and elevated (10-12 and 24-26 November) TOC over Hyderabad. The distributions of TOC for the elevated $\mathrm{O}_{3}$ cases and the tropospheric circulation prior to the correponding periods (Fig. 12a and c) are similar to the November mean (Fig. 6). These two periods are also characterized by missing data over large parts of the southern Indian Ocean and the Bay of Bengal correlated to cloudy conditions (low OLR values, not shown). The two low $\mathrm{O}_{3}$ cases (Fig. 12b and d) show very similar $\mathrm{O}_{3}$ distributions north of $10^{\circ} \mathrm{N}$ with decreased TOC over the Bay of Bengal and most of India relative to the mean November distribution. As highlighted for the Hyderabad case with the MOZAIC data, these large deviations in $\mathrm{O}_{3}$ are correlated to the crossing of the two tropical storms over India (see Sect. 3.1 and Fig. 9). The storms are responsible for large scale perturbations of the weather pattern characterized by a cyclonic circulation associated with ascending vertical velocities over the southern Bay of Bengal and southern India as shown in Fig. 12b and d. We have performed FLEXPART simulations over a large 3-D box roughly encompasing the region of decreased TOC from 75 to $85^{\circ} \mathrm{E}$ and from 10 to $25^{\circ} \mathrm{N}$. The results (not shown) are very close to the results corresponding to the Hyderabad simulations (Sect. 3.3). The only noticeable difference concerns enhanced MRTFs in the BL over the eastern coast of the Bay of Bengal, probably corresponding to transport to the south of the domain by northeasterly trades.

\section{Conclusions}

This study made use of data from the Metop/IASI sensor to determine the variability of tropospheric $\mathrm{O}_{3}$ over south Asia during the post-monsoon season of 2008. The first step has been to characterize and to validate the IASI $\mathrm{O}_{3}$ retrievals performed with the SOFRID algorithm dedicated to the op- erational processing of global IASI data. Tropospheric $\mathrm{O}_{3}$ profiles are retrieved from IASI radiances with almost two independent pieces of information (DFS $=1.7$ ), namely the TOC between the surface and $225 \mathrm{hPa}$, and the UTLS column from 225 to $70 \mathrm{hPa}$. Theoretical retrieval errors are $18 \%$ for UTLS and $15 \%$ for the troposphere while RSD of comparisons with radiosonde data are ranging from $15 \%$ at high latitude to $23 \%$ at low latitude. Both for high and low latitudes, IASI UTLS $\mathrm{O}_{3}$ columns are in excellent agreement with radiosonde data with correlation coefficient and correlation slopes very close to unity. IASI TOC are in good agreement with sonde data with slightly better results concerning high than low latitudes. The effect of the smoothing by the retrieval averaging kernels is also more pronounced when dealing with TOC than with UTLS columns highlighting differences in sensitivity in the two layers. MOZAIC airborne data at Hyderabad have been used to validate IASI TOC over central India. Thanks to their high frequency, MOZAIC data have demonstrated that IASI was able to capture the intraseasonal $\mathrm{O}_{3}$ variability in that particular region. Nevertheless, IASI detects a lower TOC variability than MOZAIC with, in particular, an overestimation of the lowest TOC. The excellent agreement between IASI TOC and MOZAIC smoothed TOC clearly indicates that the smoothing applied to the true $\mathrm{O}_{3}$ profiles by the retrieval is responsible for this partial loss of information.

More specifically, MOZAIC $\mathrm{O}_{3}$ observations allowed us to characterize variations of tropospheric $\mathrm{O}_{3}$ near Hyderabad during November and early December 2008. MOZAIC measured relatively high TOC during the post-monsoon period studied, with two important and rapid decreases. From satellite cloud images and meteorological reports we have linked these two $\mathrm{O}_{3}$ drops to the crossing of large tropical storms over central India during November 2008. We performed Lagrangian dispersion modelling with the FLEXPART model to quantify the transport pathways corresponding to high and low TOC over Hyderabad. According to FLEXPART Lagrangian simulations, the elevated $\mathrm{O}_{3}$ concentrations in the mid-troposphere mainly result from two different causes: (1) BL air-masses transported by the north-easterly trades from the polluted Indo-Gangetic plain and photochemically processed during transport (2) eastward transport of UT airmasses along the SWJ followed by subsidence over northern India, and further transport by the north-easterly trades. The anomalously low tropospheric $\mathrm{O}_{3}$ concentrations during two periods in November 2008 near Hyderabad were caused by the upward and north-westward transport of pristine MBL air masses from the Bay of Bengal associated with the crossing of the two severe tropical storms.

IASI data were used for the first time to study tropospheric $\mathrm{O}_{3}$ near a tropical region, namely south Asia. Thanks to its exceptional spatio-temporal coverage, IASI enabled to extend the determination of tropospheric $\mathrm{O}_{3}$ variability with a daily frequency at the continental scale. Comparisons with MOZAIC over Hyderabad have validated the TOC observed 
by IASI over India. IASI data have shown that the Hyderabad variability was representative of the whole of central and southern India with elevated TOC during most of the period and large drops associated to the crossing of the two tropical storms. This study has therefore highlighted the potential of IASI to characterize tropospheric $\mathrm{O}_{3}$ mesoscale variability over a tropical region, paving the way to a number of applications. The operational processing with the SOFRID software will in particular enable the use of IASI tropospheric $\mathrm{O}_{3}$ data for (i) case studies involving chemistry and transport processes, (ii) the determination of seasonal and intra-sesonal variations, and (iii) near-real time processing with an assimilation system to produce chemical weather forecasts.

Acknowledgements. The authors thank E. Borbas and R. Saunders for providing the RTTOV UW-IRemis module and the necessary support for its use. We are also thankfull to P. Brunel for providing the RTTOV regression coefficients updated with HITRAN2004. IASI has been developed and built under the responsibility of the Centre National d'Etudes Spatiales (CNES, France). It is flown onboard the MetOp satellites as part of the EUMETSAT Polar System. The IASI L1 data are received through the Eumetcast near real time data distribution service. IASI L1 and L2 data are stored in the Ether French atmospheric database (http://ether.ipsl.jussieu.fr). The research concerning IASI is conducted with the financial support of CNES. The authors acknowledge for the strong support of the European Commission, Airbus, and the Airlines (Austrian-Airlines, Austrian, Air France) who carry free of charge the MOZAIC equipment and perform the maintenance since 1994. MOZAIC is presently funded by INSU-CNRS, Meteo-France, and FZJ (Forschungszentrum Julich, Germany). Interpolated OLR data are provided by the NOAA/OAR/ESRL PSD, Boulder, Colorado, USA, from their web site at http://www.cdc.noaa.gov. The satellite images of the storms were provided by the NERC Satellite Receiving Station, Dundee University, Scotland (http://www.sat.dundee.ac.uk/).

Edited by: T. J. Dunkerton

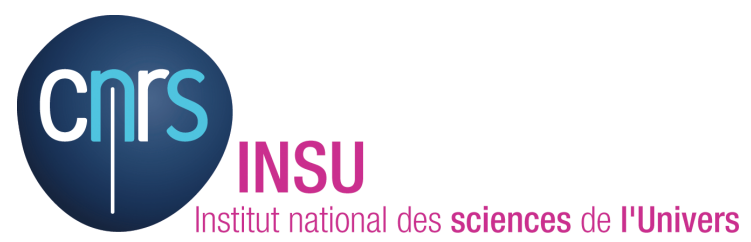

The publication of this article is financed by CNRS-INSU.

\section{References}

Barret, B., Turquety, S., Hurtmans, D., Clerbaux, C., Hadji-Lazaro, J., Bey, I., Auvray, M., and Coheur, P.-F.: Global carbon monoxide vertical distributions from spaceborne high-resolution FTIR nadir measurements, Atmos. Chem. Phys., 5, 2901-2914, doi:10.5194/acp-5-2901-2005, 2005.

Barret, B., Ricaud, P., Mari, C., Attié, J.-L., Bousserez, N., Josse, B., Le Flochmoën, E., Livesey, N. J., Massart, S., Peuch, V.-
H., Piacentini, A., Sauvage, B., Thouret, V., and Cammas, J.P.: Transport pathways of $\mathrm{CO}$ in the African upper troposphere during the monsoon season: a study based upon the assimilation of spaceborne observations, Atmos. Chem. Phys., 8, 3231-3246, doi:10.5194/acp-8-3231-2008, 2008.

Beer, R., Glavich, T. A., and Rider, D. M.: Tropospheric emission spectrometer for the Earth Observing System's Aura satellite, Appl. Optics, 40, 2356-2367, doi:10.1364/AO.40.002356, 2001.

Borbas, E. E. and Ruston, B. C.: The RTTOV UWiremis IR land surface emissivity module, AS Mission Report NWPSAF-MOVS-042, EUMETSAT Numerical Weather Prediction Satellite Applications Facility, Met Office, Exeter, U.K.

Barry, R. G. and Chorley, R. J.: Atmosphere, Weather and Climate, Routledge, London, New-York, 1995.

Boynard, A., Clerbaux, C., Coheur, P.-F., Hurtmans, D., Turquety, S., George, M., Hadji-Lazaro, J., Keim, C., and MeyerArnek, J.: Measurements of total and tropospheric ozone from IASI: comparison with correlative satellite, ground-based and ozonesonde observations, Atmos. Chem. Phys., 9, 6255-6271, doi:10.5194/acp-9-6255-2009, 2009.

Chatfield, R.B., Guan, H., Thompson, A. M., and Smith, H. G. $\mathrm{J}$.: Mechanisms for the intraseasonal variability of tropospheric ozone over the Indian Ocean during the winter monsoon, J. Geophys. Res., 112, D10303, doi:10.1029/2006JD007347, 2007.

Clerbaux, C., Boynard, A., Clarisse, L., George, M., Hadji-Lazaro, J., Herbin, H., Hurtmans, D., Pommier, M., Razavi, A., Turquety, S., Wespes, C., and Coheur, P.-F.: Monitoring of atmospheric composition using the thermal infrared IASI/MetOp sounder, Atmos. Chem. Phys., 9, 6041-6054, doi:10.5194/acp-9-6041-2009, 2009.

Clough, S. A., Shephard, M. W., Mlawer, E. J., Delamere, J. S., Iacono, M. J., Cady-Pereira, K., Boukabara, S., and Brown, P. D.: Atmospheric radiative transfer modeling: A summary of the AER codes, J. Quant. Spectrosc. Ra., 91, 233-244, 2005.

Coheur, P. F., Barret, B., Turquety, S., Hurtmans, D., Hadji-Lazaro, J., and Clerbaux, C.: Retrieval and characterization of ozone vertical profiles from a thermal infrared nadir sounder, J. Geophys. Res., 110, D24303, doi:10.1029/2005JD005845, 2005.

Dentener, F., Stevenson, D., Ellingsen, K., van Noije, T., Schultz, M., Amann, M., Atherton, C., Bell, N., Bergmann, D., Bey, I., Bouwman, L., Butler, T., Cofala, J., Collins, B., Drevet, J., Doherty, R., Eickhout, B., Eskes, H., Fiore, A., Gauss, M., Hauglustaine, D., Horowitz, L., Isaksen, I.S.A., Josse, B., Lawrence, M., Krol, M., Lamarque, J.F., Montanaro, V., Muller, J.F., Peuch, V.H., Pitari, G., Pyle, J., Rast, S., Rodriguez, J., Sanderson, M., Savage, N.H., Shindell, D., Strahan, S., Szopa, S., Sudo, K., Van Dingenen, R., Wild, O. and Zeng, G., The global atmospheric environment for the next generation, Environ. Sci. Technol., 40, 3586-3594, doi:10.1021/es0523845, 2006.

de Laat A.T.J. and Lelieveld J.: Interannual variability of the Indian winter monsoon circulation and consequences for pollution levels, J. Geophys. Res., 107, 4739, doi:10.1029/2001JD001483, 2002.

El Amraoui, L., Atti, J.-L., Semane, N., Claeyman, M., Peuch, V.H., Warner, J., Ricaud, P., Cammas, J.-P., Piacentini, A., Josse, B., Cariolle, D., Massart, S., and Bencherif, H.: Midlatitude stratosphere - troposphere exchange as diagnosed by MLS $\mathrm{O}_{3}$ and MOPITT CO assimilated fields, Atmos. Chem. Phys., 10, 2175-2194, doi:10.5194/acp-10-2175-2010, 2010. 
Emanuel, K. A. and Zivkovic-Rothman, M.: Development and evaluation of a convection scheme for use in climate models, J. Atmos. Sci., 56, 1766-1782, 1999.

Eremenko, M., Dufour, G., Foret, G., Keim, C., Orphal, J., Beekmann, M., Bergametti, G., and Flaud, J. M.: Tropospheric ozone distributions over Europe during the heat wave in July 2007 observed from infrared nadir spectra recorded by IASI, Geophys. Res. Lett., 35, L18805, doi:10.1029/2008GL034803, 2008.

George, M., Clerbaux, C., Hurtmans, D., Turquety, S., Coheur, P.F., Pommier, M., Hadji-Lazaro, J., Edwards, D. P., Worden, H., Luo, M., Rinsland, C., and McMillan, W.: Carbon monoxide distributions from the IASI/METOP mission: evaluation with other space-borne remote sensors, Atmos. Chem. Phys., 9, 8317-8330, doi:10.5194/acp-9-8317-2009, 2009.

Gupta, S., Lal, S., Venkataramani, S., Rajesh, T. A., and Acharya, Y. B.: Variability in the vertical distribution of ozone over a subtropical site in India during a winter month, J. Atmos. Terr. Phys., 69, 1502-1512, doi:10.1016/j.jastp.2007.05.011, 2007.

Keim, C., Eremenko, M., Orphal, J., Dufour, G., Flaud, J.-M., Höpfner, M., Boynard, A., Clerbaux, C., Payan, S., Coheur, P.F., Hurtmans, D., Claude, H., Dier, H., Johnson, B., Kelder, H., Kivi, R., Koide, T., Lpez Bartolom, M., Lambkin, K., Moore, D., Schmidlin, F. J., and Stbi, R.: Tropospheric ozone from IASI: comparison of different inversion algorithms and validation with ozone sondes in the northern middle latitudes, Atmos. Chem. Phys., 9, 9329-9347, doi:10.5194/acp-9-9329-2009, 2009.

Lal, S. and Lawrence M. G.: Elevated mixing ratios of surface ozone over the Arabian Sea, Geophys. Res. Lett., 28, 8, 14871490, 2001.

Lal, S., Chand D., and Sahu, L. K.: High levels of ozone and related gases over the Bay of Bengal during winter and early spring of 2001, Atmos. Environ., 40, 1633-1644, 2006.

Livesey, N. J., Filipiak, M. J., Froidevaux, L., Read, W. G., Lambert, A., Santee, M. L., Jiang, J. H., Pumphrey, H. C., Waters, J. W., Cofield, R. E., Cuddy, D. T., Daffer, W. H., Drouin, B. J., Fuller, R. A., Jarnot, R. F., Jiang, Y. B., Knosp, B. W., Li, Q. B., Perun, V. S., Schwartz, M. J., Snyder, W. V., Stek, P. C. , Thurstans, R. P., Wagner, P. A., Avery, M., Browell, E. V., Cammas, J.-P., Christensen, L. E., Diskin, G. S., Gao, R.-S., Jost, H.-J., Loewenstein, M., Lopez, J. D. , Nedelec, P., Osterman, G. B., Sachse, G. W., and Webster, C. R.: Validation of aura microwave limb sounder $\mathrm{O}_{3}$ and $\mathrm{CO}$ observations in the upper troposphere and lower stratosphere, J. Geophys. Res., 113, D15S02, doi:10.1029/2007JD008805, 2008.

Lawrence, M. G. and Lelieveld, J.: Atmospheric pollutant outflow from southern Asia: a review, Atmos. Chem. Phys., 10, 1101711096, doi:10.5194/acp-10-11017-2010, 2010.

Lelieveld, J., Crutzen, P. J., Ramanathan, V., Andreae, M. O., Brenninkmeijer, C. A. M., Campos, T. L., Cass, G. R., Dickerson, R. R., Fischer, H., de Gouw, J. A., Hansel, A., Jefferson, A., Kley, D., de Laat, A. T. J., Lal, S., Lawrence, M.G., Lobert, J.M., Mayol-Bracero, O.L., Mitra, A.P., Novakov, T., Oltmans, S. J., Prather, K. A., Reiner, T., Rodhe, H., Scheeren, H. A., Sikka, D., and Williams, J.: The Indian Ocean Experiment: Widespread air pollution from South and Southeast Asia, Science, 291, 10311036, 2001.

Massart, S., Clerbaux, C., Cariolle, D., Piacentini, A., Turquety, S., and Hadji-Lazaro, J.: First steps towards the assimilation of IASI ozone data into the MOCAGE-PALM system, Atmos. Chem.
Phys., 9, 5073-5091, doi:10.5194/acp-9-5073-2009, 2009.

Massart, S., Piacentini, A. and Pannekoucke, O.: Importance of using an ensemble estimated background error covariances for the quality of atmospheric ozone analyses, in review, Q. J. Roy. Meteor. Soc., 2011.

Matricardi, M., Chevallier, F., Kelly, G., and Thepaut, J. N.: An improved general fast radiative transfer model for the assimilation of radiance observations, Q. J. Roy. Meteorol. Soc., 130, 153173, 2004.

Matricardi, M.: Technical Note: An assessment of the accuracy of the RTTOV fast radiative transfer model using IASI data, Atmos. Chem. Phys., 9, 6899-6913, doi:10.5194/acp-9-6899-2009, 2009.

Pavelin, E. G., English, S. J., and Eyre, J. R.: The assimilation of cloud-affected infrared satellite radiances for numerical weather prediction, Q. J. R. Meteorol. Soc., 134, 737-749, 2008.

Rothman, L. S., Jacquemart, D., Barbe, A., Benner, D. C. , Birk, M., Brown, L. R., Carleer, M. R., Chackerian, C., Chance, K., Coudert, L. H., Dana, V., Devi, V. M., Flaud, J. M., Gamache, R. R., Goldman, A., Hartmann, J. M., Jucks, K. W., Maki, A. G., Mandin, J. Y., Massie, S. T., Orphal, J., Perrin, A., Rinslan, C. P., Smith, M. A. H., Tennyson, J., Tolchenov, R. N., Toth, R. A., Vander Auwera, J., Varanasi, P., and Wagner, G.: The HITRAN 2004 molecular spectroscopic database, J. Quant. Spectrosc. Ra., 96, 139-204, 2005.

Rodgers, C. D.: Inverse methods for atmospheric sounding: Theory and Practice, Series on Atmospheric, Ocean. Planet. Phys., 2, World Scientific, 2000.

Sahu, L. K., Lal, S., Thouret V., and Smit, H. G.: Seasonality of tropospheric ozone and water vapor over Delhi, India: a study based on MOZAIC measurement data, J. Atmos. Chem., 63, 151-174, 2009.

Saunders, R., Matricardi, M., and Brunel, P.: An improved fast radiative transfer model for assimilation of satellite radiance observations, Q. J. R. Meteorol. Soc., 125, 556 part B, 1407-1425, doi:10.1256/smsqj.55614, 1999.

Seemann, S. W., Borbas, E. E., Knuteson, R. O., Stephenson, G. R., and Huang, H.-L.: Development of a Global Infrared Land Surface Emissivity Database for Application to Clear Sky Sounding Retrievals from Multi-spectral Satellite Radiance Measurements, J. Appl. Meteor. Climatol., 47, 108-123, 2008.

Stehr J. W., Ball W. P., Dickerson R. R., Doddridge, B. G., Piety, C. A., and Johnson, J. E.: Latitudinal gradients in O-3 and CO during INDOEX 1999, J. Geophys. Res., 107, 8015, doi:10.1029/2001JD000446, 2002.

Stohl, A., Hittenberger, M., and Wotawa, G.: Validation of the Lagrangian particle dispersion model FLEXPART against largescale tracer experiment data, Atmos. Environ., 32, 4245-4264, 1998.

Stohl, A. and Thomson D. J.: A density correction for Lagrangian particle dispersion models, Bound.-Lay. Meteorol., 90, 155-167, 1999.

Stohl, A., Forster, C., Frank, A., Seibert, P., and Wotawa, G.: Technical note: The Lagrangian particle dispersion model FLEXPART version 6.2, Atmos. Chem. Phys., 5, 2461-2474, doi:10.5194/acp-5-2461-2005, 2005.

Thompson, A. M., Witte, J. C., McPeters, R. D., Oltmans, S. J., Schmidlin, F. J., Logan, J. A., Fujiwara, M., Kirchhoff, V. W. J. H., Posny, F., Coetzee, G. J. R., Hoegger, B., 
Kawakami, S., Ogawa, T., Johnson, B. J., Vomel, H., and Labow, G.: Southern Hemisphere Additional Ozonesondes (SHADOZ) 1998-2000 tropical ozone climatology 2. Tropospheric variability and the zonal wave-one, J. Geophys. Res., 108, 8238, doi:10.1029/2002JD002241, 2003.

Thouret, V., Marenco, A., Logan, J. A., Nedelec, P., and Grouhel, C.: Comparisons of ozone measurements from the MOZAIC airborne program and the ozone sounding network at eight locations, J. Geophys. Res., 103, 25695-25720, 1998.
Verver, G. H. L., Sikka, D. R., Lobert, J. M., Stossmeister G., and Zachariasse M.: Overview of the meteorological conditions and atmospheric transport processes during INDOEX 1999, J. Geophys. Res., 106, 28399-28413, 2001.

Worden, J., Jones, D. B. A., Liu, J., Parrington, M., Bowman, K., Stajner, I., Beer, R., Jiang, J., Thouret, V., Kulawik, S., Li, J. L. F., Verma, S., and Worden, H.: Observed vertical distribution of tropospheric ozone during the Asian summertime monsoon, J. Geophys. Res., 114, D13304, doi:10.1029/2008JD010560, 2009. 